\title{
The probiotic potential and evaluation of the safety aspects of Enterococcus sp. strains isolated from traditionally made Serbian cheese
}

\author{
Mirjana Ž. Grujovič*, Katarina G. Mladenović, and Ljiljana R. Čomić \\ Department of Biology and Ecology, Faculty of Science, University of Kragujevac, Kragujevac, Republic of Serbia
}

GRUJOVIĆ, M. Ž., K. G. MLADENOVIĆ, LJ. R. ČOMIĆ: The probiotic potential and evaluation of the safety aspects of Enterococcus sp. strains isolated from traditionally made Serbian cheese. Vet. arhiv 91, 317326, 2021.

\begin{abstract}
The purpose of this research paper was the evaluation of the safety aspects and probiotic potential of six isolates from the genus Enterococcus isolated from traditionally made cheese. The isolates represented part of the unexplored microflora of the cheese. The tolerance of Enterococcus isolates to different gastrointestinal conditions (low $\mathrm{pH}$, the presence of pepsin, pancreatin and bile salts) were investigated. Using the microdilution method, sensitivity to clinically relevant antimicrobial agents (tetracycline, ampicillin, gentamicin, vancomycin and polymyxin B) was evaluated. The adhesion ability of autochthonous Enterococcus isolates to solvents, as well as the ability of autoaggregation and co-aggregation between them and Escherichia coli clinical isolates, was investigated. The results indicated that isolates showed tolerance to the simulated gastrointestinal condition in a high percentage. Isolates were sensitive to all the tested antibiotics, especially to ampicillin, with MIC values obtained from $0.19-2.5 \mu \mathrm{g} / \mathrm{mL}$. The isolates showed the ability of growth in medium with phenol and showed no ability to synthesize histamine and tyramine. The highest percentage of adhesion was detected with chloroform, and the lowest with xylene. The isolates showed moderate auto-aggregation ability, while a different degree of co-aggregation with E. coli was observed. The results indicated that the potential application of investigated Enterococcus isolates is selective and limited.
\end{abstract}

Key words: antibiotics; adhesion ability; aggregation ability; probiotics; safety aspect; enterococci

\section{Introduction}

One of the major criteria for autochthonous bacteria to be considered as probiotics is their resistance to gastrointestinal conditions (HERNANDEZ-HERNANDEZ et al., 2012). However, BOTES et al. (2008) indicated that one more property of a good probiotic is its adhesion to mucus and epithelial cells. The reason for this can be found in the fact that adhesion, particularly in intestinal epithelial cells, is a very important

prerequisite for colonization of the gastrointestinal tract by probiotic bacteria. Also, good bacterial adhesion can prevent their immediate elimination by peristalsis, and provide a competitive advantage in this ecosystem (KOS et al., 2003).

SOLIERI etal.(2014)indicated that the beneficial effects of probiotics are strain specific. Some studies indicated the potential use of members of the genus Enterococcus as safe probiotic candidates (FRANZ

\footnotetext{
*Corresponding author:

Grujović Mirjana, University of Kragujevac, Faculty of Science, Department of Biology and Ecology, Radoja Domanović 12, 34000 Kragujevac, Republic of Serbia, Phone: +381 34336 223; E-mail: mirkagrujovic@gmail.com
} 
et al., 2011; FERREIRA ARAÚJO and DE LUCES FORTES FERREIRA, 2013). The main species of this genus found in food are Enterococcus faecalis and Enterococcus faecium (HOSSEINI et al., 2009; MURUZOVIĆ et al., 2018a). Some authors indicated that enterococci have some desirable characteristics for this purpose, such as resistance to gastric juices and bile salts, and the production of antimicrobial compounds such as enterocins (FRANZ et al., 1999).

It has been shown that LABs, with autoaggregation ability, act on the hydrophobicity of the cell surface and had a better ability to adhere to intestinal cell surfaces (DEL RE et al., 2000). Many authors indicated that LABs, with co-aggregation ability, may form a barrier that prevents colonization by pathogenic microorganisms (DEL RE et al., 2000; KOS et al., 2003; ASLIM et al., 2007; YONES et al., 2012; PRINGSULAKA et al., 2015). LABs, which use co-aggregation ability with some pathogenic strains, which mostly belong to the gastrointestinal and urogenital tracts, could inhibit their growth (BOTES et al., 2008). LI et al. (2015) showed that LABs (Lactobacillus, Lactococcus, and Enterococcus), isolated from Chinese traditional fermented food, had a good co-aggregation ability with Salmonella spp. STEVENS et al. (2015) demonstrated the ability of co-aggregation between E. faecalis MF328, isolated from food, with bacteria isolated from different environmental sources.

However, very few Enterococcus strains have been used as probiotics or feed additives because of the safety concerns associated with their pathogenic traits as opportunistic microorganisms. Numerous enterococcal strains are known for carrying virulence factors, which includes resistance to antibiotics. This is the most dangerous characteristic for probiotics, related to the ability of horizontal transfer of genes from beneficial bacteria to pathogens (BILLSTRÖM et al., 2008; BRAIEK and SMAOUI, 2019).

The aims of this study were the evaluation of the tolerance of indigenous Enterococcus isolates to different gastrointestinal conditions, their sensitivity to antibiotics, their ability to synthesize biogenic amines and to grow on media with phenol, as well as the detection of hemolysis on blood agar.
Also, the aims were the evaluation of the autoaggregation, co-aggregation and adhesiveness abilities of indigenous isolates.

\section{Materials and methods}

Microorganisms used in study. Six isolates from the genus Enterococcus (Enterococcus hirae KGPMF9, Enterococcus durans KGPMF0, Enterococcus faecium KGPMF14, Enterococcus faecalis KGPMF47, E. faecalis KGPMF48, E. faecalis KGPMF49) were used in this study. All tested bacteria were isolated from cheese from Sokobanja (Southeastern Serbia), and provided by the Microbiology Laboratory, Faculty of Science, University of Kragujevac, Serbia. The cheese was made in a traditional way, without adding any bacterial starter culture, so the isolates tested in this study represent the natural cheese microflora. The isolates were chosen according to their previously investigated biochemical characteristics and antagonistic potential against enterobacteria isolated from the same cheese (MURUZOVIĆ et al., 2018a; GRUJOVIĆ et al. 2019). The bacterial strains were kept in glycerol stock at $-80{ }^{\circ} \mathrm{C}$. Enterococcus faecalis ATCC 29211 was used as a reference strain. Escherichia coli, a clinical isolate, was a generous gift from the Institute of Public Health, Kragujevac, Serbia. Before experimental use, working cultures were subcultured twice in MRS broth.

Simulated gastrointestinal transit tolerance assay. The acid tolerance of LAB was studied in different $\mathrm{pH}$ solutions, which were prepared by adjusting hydrochloric acid $(\mathrm{HCl})$ (Zorka Šabac, Šabac, Serbia) to $\mathrm{pH}$ levels of 3, 4 and 5, as described in GRUJOVIĆ et al. (2019a).

Simulated gastric and small intestinal juice tolerance assays were performed according to the method described in HUANG and ADAMS (2004), with some modifications described in GRUJOVIĆ et al. (2019a). Gastric juice was prepared by suspending $0.22 \%(\mathrm{w} / \mathrm{v})$ pepsin (Merck, New Jersey, USA) in sterile filtered $0.5 \%(\mathrm{w} / \mathrm{v}) \mathrm{NaCl}$ solution, with the $\mathrm{pH}$ adjusted to 2 . Incubation was conducted at $37^{\circ} \mathrm{C} / 3 \mathrm{~h}$. The results were determined by an ELISA plate reader at $600 \mathrm{~nm}$, in triplicate (BASSYOUNI et al., 2012). 
Small intestinal juice was prepared by suspending $0.2 \%(\mathrm{w} / \mathrm{v})$ of pancreatin (SigmaAldrich, St. Louis, USA) in filter sterile $0.5 \%$ $\mathrm{NaCl}(\mathrm{w} / \mathrm{v})$ solution with $0.4 \%$ bile salts (SigmaAldrich, St. Louis, USA) and adjusting the $\mathrm{pH}$ to 8 by adding sterile $0.1 \mathrm{M} \mathrm{NaOH}$. Ninety-six-well microtiter plates were incubated at $37^{\circ} \mathrm{C} / 4 \mathrm{~h}$. The results were performed in triplicate. The number of viable enterococci was determined by transferring the appropriate samples onto the MRS agar plates. The percentage of survival was calculated using the following formula:

$\%$ survival $=(\beta / \alpha) \times 100$

$\alpha-\mathrm{CFU} / \mathrm{mL}$ of the assayed strain (uninoculated MRS (pH 6.5), at $37{ }^{\circ} \mathrm{C} / 48 \mathrm{~h}$ ); $\beta$ - CFU/mL of the same strain after incubation under different gastrointestinal conditions.

Synthesis of biogenic amines and growth in the presence of phenol. The ability of the isolates to synthesize biogenic amines (histamine and tyramine) from histidine and tyrosine was analyzed by the method described in JEONG and LEE (2015). The growth of isolates in the presence of phenol was determined as described in ŠUŠKOVIĆ et al. (2001).

Evaluation of auto-aggregation and coaggregation ability. The auto-aggregation ability of Enterococcus isolates, as well as the co-aggregation ability with $E$. coli was monitored by the method described in TUO et al. (2013), with the modification described in GRUJOVIĆ et al. (2019a).

Microbial adhesion to solvents. Microbial adhesion to solvents (MATS) was measured according to the method described in COLLADO et al. (2008), with modifications described in GRUJOVIĆ et al. (2019a). Three different solvents were tested in this study: xylene (Sineks, Belgrade, Serbia), which is an apolar solvent; chloroform (Alkaloid, Skoplje, Macedonia), a monopolar and acidic solvent; and ethyl acetate (Zorka Šabac, Šabac, Serbia) a monopolar and basic solvent. Only bacterial adhesion to xylene reflects cell surface hydrophobicity or hydrophilicity. The values of MATS obtained with the two other solvents, chloroform, and ethyl acetate, were regarded as a measure of the electron donor (basic) and electron acceptor (acidic) characteristics of the bacteria, respectively.

Safety assessment. The safety of enterococci was assessed by detection of hemolysis on blood agar plates, with an evaluation of their sensitivity to clinically relevant antibiotics.

The hemolytic activity of Enterococcus isolates was examined by culturing fresh overnight cultures on Columbia agar plates (Oxoid) containing 7\% $(\mathrm{v} / \mathrm{v})$ sheep blood (Oxoid), incubated for $48 \mathrm{~h}$ at $37{ }^{\circ} \mathrm{C}$. Hemolytic activities were detected as the appearance of a halo around the colony: a greenish zone was considered $\alpha$-hemolysis, a clear zone $\beta$-hemolysis and no halo $\gamma$-hemolysis (ABEDI et al., 2018).

The antibiotic sensitivity of enterococci was tested using the microdilution method with resazurin (SARKER et al., 2007), by determining the minimum inhibitory concentration (MIC) The followed antibiotics were used for this study: tetracycline, ampicillin, gentamicin, vancomycin and polymyxin B (Sigma Chemicals Co., USA), in a concentration range from $0.05-4000 \mu \mathrm{g} / \mathrm{mL}$. The method was described in detail in MURUZOVIĆ et al. (2016).

Statistical analysis. All data were presented as means \pm standard deviations, using Microsoft Excel (Redmond, Washington, DC, USA). Differences between bacterial survival in gastrointestinal conditions, as well as sensitivity to the tested antibiotics, were tested using one-way ANOVA and Paired-T test. A paired T-test was used for statistical processing of the results of adhesion to different solvents. Spearman's correlation coefficient was used for determination of a correlation between the auto-aggregation and hydrophobicity of the tested bacteria. All statistical analyses were performed using SPSS (IBM SPSS Statistics 20).

\section{Results}

Simulated gastrointestinal transit tolerance assay. It is desirable that potential probiotic strains show tolerance to low $\mathrm{pH}$, since they pass through stomach conditions. In this test, all the isolates showed the ability of growth at low $\mathrm{pH}$, although the optical densities of bacterial growth were reduced (Table 1). 
M. Ž. Grujović et al.: Probiotic potential and evaluation of safety aspect of Enterococcus sp. strains isolated from traditionally made Serbian cheese

Table 1. Resistance of Enterococcus isolates to low $\mathrm{pH}$

\begin{tabular}{|l|c|c|c|c|}
\hline Isolates & Growth control & $\mathrm{pH}$ & $\mathrm{pH} 4$ & $\mathrm{pH} \mathrm{3}$ \\
\hline E. hirae KGPMF9 & $0.22 \pm 0.04$ & $0.16 \pm 0.01(72.71)^{*}$ & $0.15 \pm 0.02(68.18)^{*}$ & $0.14 \pm 0.01(63.64)^{*}$ \\
\hline E. durans KGPMF10 & $0.25 \pm 0.01$ & $0.16 \pm 0.01(64)^{*}$ & $0.14 \pm 0.02(56)^{*}$ & $0.14 \pm 0.00(56)^{*}$ \\
\hline E. faecium KGPMF14 & $0.28 \pm 0.00$ & $0.26 \pm 0.00(92.85)$ & $0.24 \pm 0.01(85.71)^{*}$ & $0.17 \pm 0.03(60.71)^{*}$ \\
\hline E. faecalis KGPMF47 & $0.26 \pm 0.04$ & $0.22 \pm 0.02(84.62)$ & $0.18 \pm 0.01(69.23)^{*}$ & $0.17 \pm 0.01(65.38)^{*}$ \\
\hline E. faecalis KGPMF48 & $0.28 \pm 0.02$ & $0.25 \pm 0.02(89.29)$ & $0.17 \pm 0.01(60.71)^{*}$ & $0.15 \pm 0.01(53.57)^{*}$ \\
\hline E. faecalis KGPMF49 & $0.26 \pm 0.06$ & $0.22 \pm 0.04(84.62)$ & $0.20 \pm 0.00(76.92)^{*}$ & $0.18 \pm 0.00(69.23)^{*}$ \\
\hline E. faecalis ATCC 29211 & $0.28 \pm 0.05$ & $0.08 \pm 0.05(28.57)^{*}$ & $0.07 \pm 0.04(25.00)^{*}$ & $0.04 \pm 0.03(14.29)^{*}$ \\
\hline
\end{tabular}

Values are presented as mean \pm SD measured at $600 \mathrm{~nm}$; growth percentages are given in parentheses; *statistical significance $(\mathrm{P}<0.05)$ of the growth of bacteria compared with growth control

Table 2. Tolerance of Enterococcus isolates to simulated gastric juice tolerance

\begin{tabular}{|l|c|c|c|c|}
\hline Isolates & $1^{\mathrm{h}}$ & $2^{\mathrm{h}}$ & $3^{\mathrm{h}}$ & $\begin{array}{c}\% \text { of surviving after } \\
3^{\mathrm{h}}(\mathrm{CFU} / \mathrm{mL})\end{array}$ \\
\hline E. hirae KGPMF9 & $0.12 \pm 0.00(92.31)$ & $0.12 \pm 0.00(92.31)$ & $0.12 \pm 0.00(92.31)$ & $90 \pm 0.64$ \\
\hline E. durans KGPMF10 & $0.27 \pm 0.02(90)$ & $0.24 \pm 0.01(80)$ & $0.20 \pm 0.02(66.67)^{*}$ & $56.9 \pm 0.60$ \\
\hline E. faecium KGPMF14 & $0.15 \pm 0.00(100)$ & $0.13 \pm 0.01(86.67)$ & $0.12 \pm 0.00(80)^{*}$ & $82.9 \pm 2.33$ \\
\hline E. faecalis KGPMF47 & $0.15 \pm 0.00(100)$ & $0.14 \pm 0.03(93.33)$ & $0.13 \pm 0.01(86.67)$ & $85.5 \pm 0.20$ \\
\hline E. faecalis KGPMF48 & $0.18 \pm 0.02(85.71)$ & $0.18 \pm 0.02(85.71)$ & $0.17 \pm 0.02(80.95)^{*}$ & $80.9 \pm 4.56$ \\
\hline E. faecalis KGPMF49 & $0.15 \pm 0.01(100)$ & $0.14 \pm 0.04(93.33)$ & $0.13 \pm 0.02(86.67)^{*}$ & $86.4 \pm 0.36$ \\
\hline E. faecalis ATCC 29211 & $0.10 \pm 0.01(66.67)$ & $0.10 \pm 0.01(66.67)$ & $0.09 \pm 0.02(60)^{*}$ & $72.8 \pm 2.12$ \\
\hline
\end{tabular}

Values are presented as mean \pm SD measured at $600 \mathrm{~nm}$; percentages of growth compared with growth of control are given in parentheses; *Significant differences $(\mathrm{P}<0.05)$ at $0 \mathrm{~h}$

Table 3. Tolerance of Enterococcus isolates to stimulated small intestinal juice

\begin{tabular}{|c|c|c|c|c|c|}
\hline Isolates & $1^{\mathrm{h}}$ & $2^{\mathrm{h}}$ & $3^{\mathrm{h}}$ & $4^{\mathrm{h}}$ & $\begin{array}{c}\% \text { of surviving } \\
\text { after } 4^{\mathrm{h}}(\mathrm{CFU} / \mathrm{mL})\end{array}$ \\
\hline $\begin{array}{l}\text { E. hirae } \\
\text { KGPMF9 }\end{array}$ & $\begin{array}{l}0.13 \pm 0.02 \\
(54.17)\end{array}$ & $\begin{array}{l}0.14 \pm 0.03 \\
\quad(58.33)\end{array}$ & $\begin{array}{l}0.14 \pm 0.02 \\
(58.33)\end{array}$ & $\begin{array}{c}0.14 \pm 0.02 \\
(58.33)\end{array}$ & $56.3 \pm 0.88$ \\
\hline $\begin{array}{l}\text { E. durans KG- } \\
\text { PMF10 }\end{array}$ & $\begin{array}{l}0.24 \pm 0.01 \\
(82.76)^{*}\end{array}$ & $\begin{array}{l}0.25 \pm 0.01 \\
(86.21)^{*}\end{array}$ & $\begin{array}{c}0.21 \pm 0.02 \\
(72.41)\end{array}$ & $\begin{array}{c}0.21 \pm 0.00 \\
(72.41)\end{array}$ & $30.4 \pm 0.12$ \\
\hline $\begin{array}{l}\text { E. faecium KG- } \\
\text { PMF } 14\end{array}$ & $\begin{array}{l}0.12 \pm 0.00 \\
\quad(52.17)\end{array}$ & $\begin{array}{c}0.13 \pm 0.00 \\
(56.52)^{*}\end{array}$ & $\begin{array}{c}0.11 \pm 0.01 \\
(47.82)\end{array}$ & $\begin{array}{c}0.10 \pm 0.00 \\
(43.47)\end{array}$ & $40.5 \pm 0.36$ \\
\hline $\begin{array}{l}\text { E. faecalis KG- } \\
\text { PMF47 }\end{array}$ & $\begin{array}{c}0.15 \pm 0.00 \\
(60)\end{array}$ & $\begin{array}{c}0.16 \pm 0.00( \\
64)^{*}\end{array}$ & $\begin{array}{c}0.15 \pm 0.01 \\
(60)\end{array}$ & $\begin{array}{c}0.14 \pm 0.01 \\
(56)\end{array}$ & $52.3 \pm 0.64$ \\
\hline $\begin{array}{l}\text { E. faecalis KG- } \\
\text { PMF48 }\end{array}$ & $\begin{array}{c}0.19 \pm 0.02 \\
(82.61)^{*}\end{array}$ & $\begin{array}{l}0.21 \pm 0.02 \\
(91.30)^{*}\end{array}$ & $\begin{array}{c}0.18 \pm 0.00 \\
(78.26)^{*}\end{array}$ & $\begin{array}{c}0.17 \pm 0.00 \\
(73.91)^{*}\end{array}$ & $52.7 \pm 0.16$ \\
\hline $\begin{array}{l}\text { E. faecalis KG- } \\
\text { PMF49 }\end{array}$ & $\begin{array}{c}0.11 \pm 0.01 \\
(44)\end{array}$ & $0.12 \pm 0.00(48)^{*}$ & $\begin{array}{c}0.11 \pm 0.00 \\
(44)\end{array}$ & $\begin{array}{c}0.11 \pm 0.00 \\
(44)\end{array}$ & $40.4 \pm 0.26$ \\
\hline $\begin{array}{l}\text { E. faecalis } \\
\text { ATCC } 29211\end{array}$ & $\begin{array}{l}0.10 \pm 0.01 \\
\quad(66.67)\end{array}$ & $\begin{array}{l}0.08 \pm 0.01 \\
(53.33)\end{array}$ & $\begin{array}{c}0.05 \pm 0.00 \\
(33.33)^{*}\end{array}$ & $\begin{array}{c}0.05 \pm 0.02 \\
(33.33)^{*}\end{array}$ & $26.7 \pm 0.54$ \\
\hline
\end{tabular}

Absorbance values are presented as mean \pm SD measured at $600 \mathrm{~nm}$; growth percentages are given in parentheses;

${ }^{*}$ Significant differences $(\mathrm{P}<0.05)$ at $0 \mathrm{~h}$ 


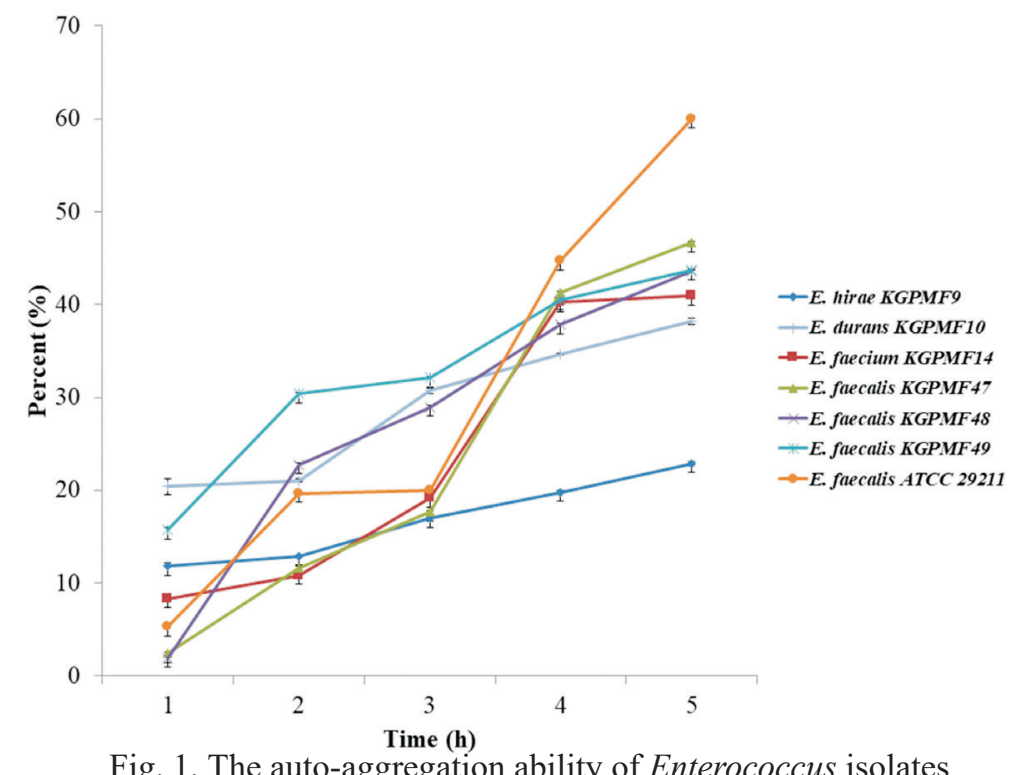

Fig. 1. The auto-aggregation ability of Enterococcus isolates

KGPMF9, KGPMF10, and KGPMF48 isolates showed a slight decrease in growth after $1 \mathrm{~h}$ of incubation. After $3 \mathrm{~h}$ of incubation, only the KGPMF47 isolate showed continuous growth. The percentage of survival was in the range of 56.990\% (Table 2).

The growth of all isolates after $4 \mathrm{~h}$ of incubation in stimulated small intestinal juice showed a further decrease. The percentage of survival of enterococci was in the range of 30.4-56.3\% (Table 3).

Synthesis of biogenic amines and growth in the presence of phenol. Enterococcus isolates showed no ability to synthesize histamine and tyramine (biogenic amines), but showed the ability of growth in the medium with $0.1,0.2$ and $0.3 \%$ of phenol.

The adhesion, auto-aggregation and coaggregation ability of Enterococcus isolates. The auto-aggregation ability of Enterococcus sp. strains isolated from traditionally made cheese from Southeastern Serbia was measured over a period of $5 \mathrm{~h}$. The results showed that the tested strains exhibited a selective auto-aggregating phenotype. The tested Enterococcus isolates showed moderate auto-aggregation ability (Fig. 1). The percentage of auto-aggregation attained after 5 hours range from 22.9 to $46.64 \%$.

The co-aggregation ability of Enterococcus isolates with E. coli also was examined (Table 4).
Table 4. Co-aggregation ability of Enterococcus isolates after $2 \mathrm{~h}$ incubation at room temperature in PBS

\begin{tabular}{|l|c|}
\hline solates & $\begin{array}{c}\text { Co-aggregation with } \\
\text { E. coli }(\%)\end{array}$ \\
\hline E. hirae KGPMF9 & $15.13 \pm 0.44^{\mathrm{a}}$ \\
\hline E. durans KGPMF10 & $23.32 \pm 0.36^{\mathrm{b}}$ \\
\hline E. faecium KGPMF14 & 0 \\
\hline E. faecalis KGPMF47 & $10.53 \pm 1.56^{\mathrm{a}, \mathrm{c}}$ \\
\hline E. faecalis KGPMF48 & 0 \\
\hline E. faecalis KGPMF49 & 0 \\
\hline E. faecalis ATCC 29211 & $15.22 \pm 0.87^{\mathrm{a}, \mathrm{c}, \mathrm{d}}$ \\
\hline
\end{tabular}

Results are presented as mean \pm SD from three separate experiments; Means of the isolates with different letters in superscript are significantly different $(\mathrm{P}<0.05)$

The results are expressed as the percentage of co-aggregation after $2 \mathrm{~h}$ in the absorbance of a mixed suspension. All tested Enterococcus isolates showed selectively and strain specific coaggregation ability, with results ranging from 10.53 to $23.32 \%$.

The MATS method was used to evaluate the hydrophobic/hydrophilic cell surface properties of members from the genus Enterococcus, isolated from the cheese. E. faecalis ATCC 29211 was used for comparative purposes. In order to assess the Lewis acid-base characteristics of the bacterial cell 
M. Ž. Grujović et al.: Probiotic potential and evaluation of safety aspect of Enterococcus sp. strains isolated from traditionally made Serbian cheese

Table 5. The adhesion ability of Enterococcus isolates to xylene, chloroform and ethyl acetate

\begin{tabular}{|l|c|c|c|}
\hline \multirow{2}{*}{ Isolates } & \multicolumn{3}{|c|}{ Adhesion (\%) } \\
\cline { 2 - 4 } & Xylene & Chloroform & Ethyl acetate \\
\hline E. hirae KGPMF9 & 0 & $14.21 \pm 0.08$ & 0 \\
\hline E. durans KGPMF10 & 0 & $3.85 \pm 1.56$ & 0 \\
\hline E. faecium KGPMF14 & 0 & $13.17 \pm 0.41^{\mathrm{a}}$ & $9.41 \pm 0.12^{\mathrm{a}}$ \\
\hline E. faecalis KGPMF47 & 0 & $23.97 \pm 0.63^{\mathrm{a}}$ & $15.86 \pm 0.74^{\mathrm{b}}$ \\
\hline E. faecalis KGPMF48 & 0 & $22.48 \pm 0.84^{\mathrm{a}}$ & $6.24 \pm 0.24^{\mathrm{b}}$ \\
\hline E. faecalis KGPMF49 & 0 & $5.4 \pm 0.04^{\mathrm{a}}$ & $3.17 \pm 1.36^{\mathrm{a}}$ \\
\hline E. faecalis ATCC 29211 & 0 & $19.66 \pm 1.24^{\mathrm{a}}$ & $12.13 \pm 1.05^{\mathrm{b}}$ \\
\hline
\end{tabular}

Results are presented as mean \pm SD from three separate experiments; Means in the two solvent columns or each particular isolate, with superscript with different letters, are significantly different $(\mathrm{P}<0.05)$

Table 6. Antibiotic sensitivity of Enterococcus isolates

\begin{tabular}{|l|c|c|c|c|c|}
\hline \multirow{2}{*}{ Isolates } & Tetracycline & Gentamicin & Polymyxin B & Ampicillin & Vancomycin \\
\cline { 2 - 6 } & \multicolumn{5}{|c|}{ MIC $^{*}$} \\
\hline E. hirae KGPMF9 & 6.25 & 25 & 250 & 2.5 & 125 \\
\hline E. durans KGPMF10 & 2.5 & 25 & 125 & 2.5 & 125 \\
\hline E. faecium KGPMF14 & 2.5 & 25 & 125 & 0.19 & 125 \\
\hline E. faecalis KGPMF47 & 12.5 & 25 & 250 & 0.19 & 125 \\
\hline E. faecalis KGPMF48 & 12.5 & 25 & 250 & 2.5 & 125 \\
\hline E. faecalis KGPMF49 & 2.5 & 50 & 250 & 2.5 & 125 \\
\hline E. faecalis ATCC 29211 & 8 & n.d. & n.d. & 1 & 250 \\
\hline
\end{tabular}

MIC-minimal inhibitory concentration; "Values are given in $\mu \mathrm{g} / \mathrm{mL}$; n.d. - not determined

surfaces, bacterial adhesion to chloroform and ethyl acetate was tested. The results indicated that the tested bacteria had a stronger affinity to chloroform, which is an acidic solvent and electron acceptor, than to ethyl acetate, which is a basic solvent and electron donor (Table 5). On the basis of these results, it may be concluded that the adhesion of the tested enterococci was selective and strain-specific. No affinity for xylene was observed.

Safety assessment. The results of the hemolytic activity indicated that Enterococcus isolates showed $\alpha$-hemolysis. None of the tested isolates showed $\beta$-hemolysis.

The sensitivity of isolates against antibiotics was tested (Table 6). The results were checked according to the LAB resistance criteria proposed for antibiotics of human and veterinary importance by the European Food Safety Authority (EFSA).

Enterococcus isolates showed significant sensitivity to ampicillin and tetracycline, compared to the other tested antibiotics $(\mathrm{P}<0.05)$. MIC values obtained were from 2.5 to $12.5 \mu \mathrm{g} / \mathrm{mL}$ for tetracycline and from 0.19 to $2.5 \mu \mathrm{g} / \mathrm{mL}$ for ampicillin.

\section{Discussion}

The presence of enterococci in milk and raw milk cheeses has been traditionally considered as a result of fecal contamination, but BRAIEK and SMAOUI (2019) reported that this occurrence is not always related to fecal contamination. Moreover, it is important to note that members of the genus Enterococcus play a beneficial role in 
cheese fermentation, as well as in cheese ripening and the development of its specific flavor, texture, and taste. Previous research by MURUZOVIĆ et al. (2018a) and GRUJOVIĆ et al. (2019) was aimed at the isolation, identification and characterization of Enterococcus sp. strains from traditionally made Serbian cheese (Southeastern Serbia). So far their antimicrobial potential has been demonstrated against some members of the fam. Enterobacteriaceae isolated from the same cheese, as well as their ability for biofilm formation. In the present paper, for the first time, the probiotic potential and antimicrobial sensitivity were investigated, as well as the adhesion and aggregation ability of six selected isolates from the genus Enterococcus, isolated from the cheese in question.

The probiotic characteristics of Enterococcus strains have already been investigated in many studies and their beneficial and significant healthpromoting effects reported (ZOMMITI et al., 2018; NASCIMENTO et al., 2019; NAMI et al., 2019). However, investigation of enterococci as potential probiotics is still a controversial issue because they may have detrimental traits that make it difficult to establish a clear decision relating to enterococcal strains between emerging pathogens and potential probiotics.

The ability of enterococci to grow in broth supplemented with $40 \%$ of bile salts and to hydrolyze esculin is well known. Also, they are able to grow in a huge range of $\mathrm{pH}$, from 4.4 and 9.6, and in hyper salty media with $6.5 \% \mathrm{NaCl}$ (FOULQUI'E MORENO et al., 2006). In our study, the survival rate of Enterococcus isolates in low $\mathrm{pH}$, and bile salts displayed a significant variability. This might be due to the fact that mechanisms of acid and bile tolerance are species- and strain-dependent. The tolerance to different gastrointestinal conditions (acid and bile tolerance) of the Enterococcus isolates is consistent with the results reported by NAMI et al. (2014), GUO et al. (2016), AYYASH et al. (2018) and NAMI et al. (2019).

The tested Enterococcus isolates showed no ability to synthesize histamine and tyramine (biogenic amines), which is a desirable characteristic when selecting possible probiotics (AMMOR and MAYO,
2007). They also showed ability of growth in media with $0.1,0.2$ and $0.3 \%$ of phenol. Physiological levels of phenols in humans are low. That is why it is important to analyze the sensitivity of potential probiotics to this substance.

One of the major characteristics of LABs, which can potentially be used as probiotics, is their ability for adhesion and aggregation. Auto-aggregation and co-aggregation ability are defined as the bacterial accumulation of the same species and of different species, respectively (CAMPANA et al., 2017). Auto-aggregation is correlated with adherence to epithelial cells (COLLADO et al., 2008), while coaggregation represents a defensive barrier for the colonization of pathogenic microorganisms (KOS et al., 2003; ABUSHELAIBI et al., 2017). Specific probiotic strains usually show a higher auto-aggregation ability that pathogen strains (ELHADIDY and ZAHRAN, 2014). There are studies which indicate that the biofilm formation of LABs is associated with adhesion properties, which is an important feature in gut colonization and the probiotic potential of LABs (ELHADIDY and ZAHRAN, 2014; ŽIVKOVIĆ et al., 2016; POPOVIĆ et al., 2018). Previous studies of Enterococcus sp. strains isolated from Sokobanja cheese indicated that they had the ability to produce a moderate biofilm (MURUZOVIĆ et al., 2018a, 2018b; GRUJOVIĆ et al., 2019). In the current paper, their auto- and co-aggregation ability were demonstrated.

According to AYYASH et al. (2018) and NAMI et al. (2019), hydrophobicity is one of the indicative parameters of the cell surface properties of probiotics, and it is in correlation with the adhesion ability of probiotics to epithelial cells. Selection of probiotic LABs was primarily done on the basis of their hydrophobicity against xylene (PALOMARES et al., 2007), hexadecane (PRINGSULAKA et al., 2015) and toluene (DOWARAH et al., 2018). In the current study, the tested Enterococcus isolates showed a better affinity to chloroform (acidic solvent) than to ethyl acetate (basic solvent) $(\mathrm{P}<0.05)$. LI et al. (2015) indicated that selecting LABs with higher adhering ability, according to their aggregation ability, is not a desirable method. LEE and SALMINEN (2009) and LI et al. (2015) 
showed that these characteristics were strain specific, which was confirmed in our research, too.

NAMI et al. (2019) indicated that E. durans isolates from different artisanal dairy products showed no $\beta$-hemolysis, which is agreement with the results of our study. The antibiotic sensitivity of LABs isolated from Serbian and Croatian cheeses was investigated by UROIĆ et al. (2014). They showed that all the isolates were susceptible to the antibiotics, which was confirmed in our study. NAMI et al. (2014) indicated that $E$. durans $6 \mathrm{HL}$ was sensitive to vancomycin, tetracycline, ampicillin, and gentamicin. The Enterococcus isolates tested in our study were sensitive to these antibiotics too, and showed no resistance to the tested antibiotics, according to EFSA (2012) breakpoints.

\section{Conclusion}

Enterococcus isolates from Sokobanja cheese showed tolerance to gastrointestinal conditions (mainly to bile extracts and gastric $\mathrm{pH}$ values), as well as surviving in the presence of phenols. They showed no ability for biogenic amines production, which is a desirable characteristic when selecting possible probiotics or starter cultures. Sensitivity to tested antibiotics was also noted. Adhesion ability is an important characteristic, because LABs, which process this ability, can be used as the mechanical barrier to adhesion by other bacteria, such as enterobacteria, to the epithelium. All the isolates showed moderate auto-aggregation and co-aggregation ability. Enterococcus sp. strains, isolated from the cheese from Serbia, showed probiotic potential, but they also showed the ability for $\alpha$-hemolysis. On the basis of the results presented in this paper, it could be concluded that their probiotic application is selective and limited. Further studies need to include an investigation of adherence and colonization of intestinal epithelium cells, possible in vivo studies, and a more detailed investigation of the safety aspect. Enterococcal strains investigated for potential use as probiotics in human and veterinary medicine must be wellcharacterized and completely assessed regarding safety aspects.

\section{Declaration of conflicting interests}

The author(s) declare no potential conflicts of interest with respect to the research, authorship, and/or publication of this article.

\section{Acknowledgements}

This study was supported by the Ministry of Education, Science and Technological Development of the Republic of Serbia (Agreement No. 451-03-9/2021-14/200122).

\section{References}

ABEDI, J., M. V. SAATLOO, V. NEJATI, R. HOBBENAGHI, A. TUKMECHI, Y. NAMI, A. Y. KHOSROUSHAHI (2018). Selenium-enriched Saccharomyces cerevisiae reduces the progression of colorectal cancer. Biol. Trace Elem. Res. 185, 424-432.

ABUSHELAIBI, A., S. AL-MAHADIN, K. EL-TARABILY, N. P. SHAH, M. AYYASH (2017): Characterization of potential probiotic lactic acid bacteria isolated from camel milk. LWT Food Sci. Technol. 79, 316-325.

DOI: 10.1155/2018/7970463

AMMOR, M. S., B. MAYO (2007): Selection criteria for lactic acid bacteria to be used as functional starter cultures in dry sausage production: An update. Meat Sci. 76, 138-146.

ASLIM, B., D. ONAL., Y. BEYATLI (2007): Factors influencing auto-aggregation and aggregation of Lactobacillus delbrueckii subsp. bulgaricus isolated from handmade yogurt. J. Food Prot. 70, 223-227.

AYYASH, M., A. ABUSHELAIBI, S. AL-MAHADIN, M. ENAN, K. EL-TARABILY, N. SHAH (2018): In vitro investigation into probiotic characterisation of Streptococcus and Enterococcus isolated from camel milk. LWT Food Sci. Technol. 87, 478-487.

DOI: $10.1016 /$ j.lwt.2017.09.019

BASSYOUNI, R. H., W. S. ABDEL-ALL, M. G. FADL, S. ABDEL-ALL, Z. KAMEL (2012): Characterization of lactic acid bacteria isolated from dairy products in Egypt as a probiotic. Life Sci. J. 9, 2924-2933.

BILlSTRÖM, H., B. LUND, A. SULLIVAN, C. E. NORD (2008): Virulence and antimicrobial resistance in clinical Enterococcusfaecium. Int.J.Antimicrob.Agent.32,374-377.

BOTES, M., B. LOOS, C. A. VAN REENEN, L. T. M. DICKS (2008): Adhesion of the probiotic strains Enterococcus mundtii ST4SA and Lactobacillus plantarum 423 to Caco2 cells under conditions simulating the intestinal tract, and in the presence of antibiotics and anti-inflammatory medicaments. Arch. Microbiol. 190, 573-584. DOI 10.1007/s00203-008-0408-0

BRAIEK, O. B., S. SMAOUI (2019): Enterococci: between emerging pathogens and potential probiotics. Bio. Med. Res. Int. 2019, 1 - 13. DOI: $10.1155 / 2019 / 5938210$

CAMPANA, R., S. VAN HEMERT, W. BAFFONE (2017): Strain-specific probiotic properties of lactic acid bacteria 
M. Ž. Grujović et al.: Probiotic potential and evaluation of safety aspect of Enterococcus sp. strains isolated from traditionally made Serbian cheese

and their interference with human intestinal pathogens invasion. Gut Pathog. 9, 12.

DOI: $10.1186 / \mathrm{s} 13099-017-0162-4$

COLLADO, M. C., J. MERILUOTO, S. SALMINEN (2008): Adhesion and aggregation properties of probiotic and pathogen strains. Eur. Food Res. Technol. 226, 1065-1073. DOI: 10.1007/s00217-007-0632-x

DEL RE, B., B. SGORBATI, M. MIGLIOLI, D. PALENZONA (2000): Adhesion, autoaggregation and hydrophobicity of 13 strains of Bifidobacterium longum. Lett. Appl. Microbiol. 31, 438-442.

DOWARAH, R., A. K. VERMA, N. AGARWAL, P. SINGH, B. R. SINGH (2018): Selection and characterization of probiotic lactic acid bacteria and its impact on growth, nutrient digestibility, health and antioxidant status in weaned piglets. PLoS ONE 13(3), e0192978.

DOI: 10.1371 /journal. pone. 0192978

ELHADIDY, M., E. ZAHRAN (2014): Biofilm mediates Enterococcus faecalis adhesion, invasion and survival into bovine mammary epithelial cells. Lett. Appl. Microbiol. 58, 248-254.

DOI: $10.1111 /$ lam.12184

FERREIRA ARAÚJO, T., C. L. DE LUCES FORTES FERREIRA (2013): The genus Enterococcus as probiotic: safety concerns. Braz. Arch. Biol. Technol, 56, 457-466.

FOULQUI'E MORENO, M. R., P. SARANTINOPOULOS, E. TSAKALIDOU, L. DE VUYST (2006): The role and application of enterococci in food and health. Int. J. Food Microbiol. 106, 1-24.

FRANZ, C. M., M. HUCH, H. ABRIOUEL, W. HOLZAPFEL, A. GÁLVEZ (2011): Enterococci as probiotics and their implications in food safety. Int. J. Food Microbiol. 151, 125-140.

FRANZ, C. M., W. H. HOLZAPFEL, M. E. STILES (1999): Enterococci at the crossroads of food safety? Int. J. Food Microbiol. 47, 1-24.

GRUJOVIĆ, M. Ž., K. G. MLADENOVIĆ, D. D. NIKODIJEVIĆ, L. R. ČOMIĆ (2019a): Autochthonous lactic acid bacteria - presentation of potential probiotics application. Biotechnol. Lett. 41, 1319-1331.

DOI: 10.1007/s10529-019-02729-8

GRUJOVIĆ, M. Ž., K. G. MLADENOVIĆ, T. D. ŽUGIĆ PETROVIĆ, L. R. ČOMIĆ (2019): Assessment of the antagonistic potential and ability of biofilm formation of Enterococcus spp. isolated from Serbian cheese. Vet. arh. 89, 653-667.

GUO, L., T. LI, Y. TANG, L. YANG, G. HUO (2016): Probiotic properties of Enterococcus strains isolated from traditional naturally fermented cream in China. Microb. Biotechnol. 9, 737-745.

HERNANDEZ-HERNANDEZ, O., A. MUTHAIYAN, F. J. MORENO, A. MONTILLA, M. L. SANZ, S. C. RICKEET (2012): Effect of prebiotic carbohydrates on the growth and tolerance of Lactobacillus. Food Microbiol. 30, 355-361.
HOSSEINI, S. V., S. ARLINDO, K. C. BOHME, N. FERNANDEZ, P. CALO-MATA, J. BARROSVELAZQUEZ (2009): Molecular and probiotic characterization of bacteriocin producing Enterococcus faecium strains isolated from nonfermented animal foods. J. Appl. Microbiol. 107, 1392-1403.

HUANG, Y., M. C. ADAMS (2004): In vitro assessment of the upper gastrointestinal tolerance of potential probiotic dairy propionibacteria. Int. J. Food Microbiol, 91, 253-260.

JEONG, D. W., J. H. LEE (2015): Antibiotic resistance, hemolysis and biogenic amine production assessments of Leuconostoc and Weissella isolates for kimchi starter development. LWT - Food Sci. Technol. 64, 1078-1084.

KOS, B., J. ŠUŠKOVIĆ, S. VUKOVIĆ, M. ŠIMPRAGA, J. FRECE, S. MATOŠIĆ (2003): Adhesion and aggregation ability of probiotic strain Lactobacillus acidophilus M92. J. Appl. Microbiol. 94, 981-987.

LEE, Y. K., S. SALMINEN (2009): Handbook of probiotics and prebiotics. Wiley, pp. 386.

LI, Q., X. LIU, M. DONG, J. ZHOU, Y. WANG (2015): Aggregation and adhesion abilities of 18 lactic acid bacteria strains isolated from traditional fermented food. Int. J. Agric. Policy. Res. 3, 84-92.

MURUZOVIĆ, M. Ž., K. G. MLADENOVIĆ, L. R. ČOMIĆ (2018b): In vitro evaluation of resistance to environmental stress by planktonic and biofilm form of lactic acid bacteria isolated from traditionally made cheese from Serbia. Food Biosci, 23, 54-59.

MURUZOVIĆ, M. Ž., K. G. MLADENOVIĆ, O. D. STEFANOVIĆ, S. M. VASIĆ, L. R. ČOMIĆ (2016): Extracts of Agrimonia eupatoria L. as sources of biologically active compounds and evaluation of their antioxidant, antimicrobial, and antibiofilm activities. J. Food Drug Anal. 24, 539-547.

MURUZOVIĆ, M. Ž., K. G. MLADENOVIĆ, T. D. ŽUGIĆ PETROVIĆ, L. R. ČOMIĆ (2018a): Characterization of lactic acid bacteria isolated from traditionally made Serbian cheese and evaluation of their antagonistic potential against Enterobacteriaceae. J. Food Process. Preserv. 42, e13577. DOI: $10.1111 /$ jfpp. 13577

NAMI, Y., N. ABDULLAH, B. HAGHSHENAS, D. RADIAH, R. ROSLI, A. Y. KHOSROUSHAHI (2014): Probiotic assessment of Enterococcus durans 6HL and Lactococcus lactis $2 \mathrm{HL}$ isolated from vaginal microflora. J. Med. Microbiol. 63, 1044-1051.

NAMI, Y., R. VASEGHI BAKHSHAYESH, H. MOHAMMADZADEH JALALY, H. LOTFI, S. ESLAMI, M. A. HEJAZI (2019): Probiotic properties of enterococcus isolated from artisanal dairy products. Front. Microbiol. $10,1685$.

NASCIMENTO, L. C., S. N. CASAROTTI, S. D. TODOROV, A. L. PENNA (2019): Probiotic potential and safety of enterococci strains. Ann. Microbiol. 69, 241-252.

PALOMARES, I. C., P. R. MORALES, A. E. FELIX (2007): Evaluation of probiotic properties in Lactobacillus isolated 
M. Ž. Grujović et al.: Probiotic potential and evaluation of safety aspect of Enterococcus sp. strains isolated from traditionally made Serbian cheese

from small intestine of piglets. Rev. Latinoam. Microbiol. 49, $46-54$.

POPOVIĆ, N., M. DINIĆ, M. TOLINAČKI, S. MIHAJLOVIĆ, A. TERZIĆ-VIDOJEVIĆ, S. BOJIĆ, J. DJOKIĆ, N. GOLIĆ, K. VELJOVIĆ (2018): New insight into biofilm formation ability, the presence of virulence genes and probiotic potential of Enterococcus sp. dairy isolates. Front. Microbiol. 9, 78.

DOI: $10.3389 /$ fmicb.2018.00078

PRINGSULAKA， O., K. RUEANGYOTCHANTHANA, N. SUWANNASAI, N. WATANAPOKASIN, P. AMNUEYSIT, S. SUNTHORNTHUMMAS, A. SUKKHUM, S. SARAWANEEYARUK, A. RANGSIRUJI (2015): In vitro screening of lactic acid bacteria for multistrain probiotics. Livestock Sci. 174, 66-73.

SARKER, S. D., L. NAHAR, Y. KUMARASAMY (2007): Microtitre plate-based antibacterial assay incorporating resazurin as an indicator of cell growth, and its application in the in vitro antibacterial screening of phytochemicals. Methods 42, 321-324.

SOLIERI, L., A. BIANCHI, G. MOTTOLESE, F. LEMMETTI, P. GIUDICI (2014): Tailoring the probiotic potential of non-starter Lactobacillus strains from ripened Parmigiano Reggiano cheese by in vitro screening and principal component analysis. Food Microbiol. 38, 240-249.

STEVENS, M., T. L. LUO, J. VORNHAGEN, N. S. AKUBOVICS, J. R. GILSDORF, C. F. MARRS, T. MØRETRØ, A. H. RICKARD (2015): Coaggregation occurs between microorganisms isolated from different environments. FEMS Microbiol. Ecol. 91, 1-14.

DOI: $10.1093 /$ femsec/fiv 123
ŠUŠKOVIĆ, J., B. KOS, J. GORETA, S. MATOSIĆ (2001): Role of lactic acid bacteria and bifidobacteria in symbiotic effect. Food Technol. Biotechnol. 39, 227-235.

TUO, Y., H. YU, L. AI, Z. WU, B. GUO, W. CHEN (2013): Aggregation and adhesion properties of 22 Lactobacillus strains. J. Dairy Sci. 96, 4252-4257.

UROIĆ, K., M. NIKOLIĆ, B. KOSLIĆ, L. PAVUNC, J. BEGANOVIĆ, J. LUKIĆ, B. JOVČIĆ, B. FILIPIĆ, M. MILJKOVIĆ, N. GOLIĆ, L. TOPISIROVIĆ, N. ČADEŽ, P. RASPOR, J. ŠUŠKOVIĆ (2014): Probiotic properties of lactic acid bacteria isolated from Croatian fresh soft cheese and Serbian white pickled cheese. Food Technol. Biotechnol. 52, 232-241.

YOUNES, J. A., H. C. VAN DER MEI, E. VAN DEN HEUVEL, H. J. BUSSCHER, G. REID (2012): Adhesion forces and coaggregation between vaginal staphylococci and lactobacilli. PLoS ONE 7, 1-8.

ŽIVKOVIĆ, M., M. S. MILJKOVIĆ, P. RUAS-MADIEDO, M. B. MARKELIĆ, K. VELJOVIĆ, M. TOLINAČKI, S. SOKOCIĆ, A. KORAĆ, N. GOLIĆ (2016): EPS-SJ exopolisaccharide produced by the strain Lactobacillus paracasei subsp. paracasei BGSJ2-8 is involved in adhesion to epithelial intestinal cells and decrease on $E$. coli association to Caco-2 cells. Front. Microbiol. 7, 286.

DOI: 10.3389/fmicb.2016.00286

ZOMMITI, M., M. CAMBRONEL, O. MAILLOT, M. BARREAU, K. SEBEI, M. FEUILLOLEY, M. FERCHICHI, N. CONNIL (2018): Evaluation of probiotic properties and safety of Enterococcus faecium isolated from artisanal Tunisian meat "Dried Ossban". Front. Microbiol. 9, 1685.

DOI: $10.3389 /$ fmicb.2018.01685

Received: 7 January 2020

Accepted: 22 April 2020

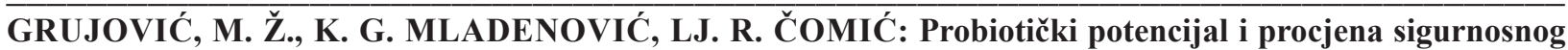
aspekta sojeva Enterococcus sp. izoliranih iz tradicionalno rađenog sira u Srbiji. Vet. arhiv 91, 317-326, 2021.

\section{SAŽETAK}

Cilj ovoga rada bio je procjena sigurnosnog aspekta i probiotičkog potencijala šest izolata roda Enterococcus izoliranih iz tradicionalno rađenog sira. Izolati su predstavljali dio neistražene mikroflore sira. Analizirana je tolerancija izolata Enterococcus na različite gastrointestinalne uvjete (nizak pH, prisutnost pepsina, pankreatina i soli žučnih kiselina). Mikrodilucijskom metodom procijenjena je osjetljivost na klinički relevantne antimikrobne agense (tetraciklin, ampicilin, gentamicin, vankomicin i polimiksin B). Istraživana je i adhezivna sposobnost autohtonih izolata Enterococcus na otapala, kao i sposobnost autoagregacije i koagregacije između njih i kliničkih izolata Escherichia coli. Izolati su pokazali toleranciju na simulirane gastrointestinalne uvjete u velikom postotku. Utvrđena je osjetljivost na sve testirane antibiotike, posebno na ampicilin, s MIC vrijednostima od 0,19 do $2,5 \mu \mathrm{g} / \mathrm{mL}$. Izolati su pokazali sposobnost rasta na hranjivoj podlozi s fenolom, a nisu pokazali sposobnost sintetizacije histamina i tiramina. Otkriveno je da je najveći postotak adhezije s kloroformom, a najmanji sa ksilenom. Izolati su pokazali umjerenu sposobnost autoagregacije, a opažen je i različit stupanj koagregacije s E. coli. Rezultati pokazuju da je potencijalna primjena istraživanih izolata bakterije Enterococcus selektivna i ograničena.

Ključne riječi: antibiotici; sposobnost adhezije; sposobnost agregacije; probiotici; sigurnosni aspekt; bakterije Enterococcus 